ISBN 978-93-84422-85-1

11th International Conference on Chemical, Agricultural, Biological and Environmental Sciences

(CABES-2018)

April 17-18, 2018 Kyoto (Japan)

\title{
Evaluation of 36 KDa Outer Membrane Protein (OMP's) by Latex Dri-Dot of Salmonella Enterica Serovar Typhi for the Diagnosis of Typhoid Fever
}

\author{
Cut Muthiadin ${ }^{1 *}$, Rossana Agus ${ }^{2}$, Isna Rasdianah Aziz ${ }^{1}$ and Mochammad Hatta ${ }^{3}$ \\ ${ }^{1 *}$ Department Biology, Alauddin Islamic State University, Indonesia \\ ${ }^{2}$ Department Biology, Hasanuddin University, Indonesia \\ ${ }^{3}$ Department Microbiology, Medical Faculty, Hasanuddin University, Indonesia
}

\begin{abstract}
Dri-dot latex which is used to clamp OMP is deep blue dyed latex beads with a diameter of $0.80 \mu \mathrm{m}$ Sigma-Aldrich production which is in the form of suspension. Purified OMP was developed from previous study. Patients suspected of typhoid who attended three hospitals were included in the study. The test results were compared with blood culture and rapid diagnostic is lateral flow kit. 25 patients were diagnosed as having typhoid fever. Results positive culture of S. Typhi bacteria were 5 (20\%), tifoid positive on 22 lateral flow (88\%), and tifoid positive using purified OMP protein at latex of 22 (88\%). OMP latex with blood culture had a sensitivity of $100 \%$, and low specificity is $21,74 \%$. Yet, different results on OMP latex with lateral flow, yield sensitivity of $95.65 \%$ and specificity of 50\%. Purified OMPs could be improved as rapid and early diagnostic test for typhoid fever.
\end{abstract}

Keywords: OMP , latex, Dri-dot, rapid test, Typhoid fever

\section{Introduction}

The diagnosis of typhoid fever based on clinical examination is difficult to enforce due to different symptoms and signs. In addition, the symptoms that appear is similar to other symptoms of diseases such as malaria and dengue fever. Isolation or blood culture is still a commonly used diagnosis as gold standard. However, the results obtained are less satisfactory culture, this is because culture takes a long time. Besides the positive results of culture is determined from the sampling and the effect of previous antibiotic treatment.

The serological test for typhoid fever that is widely used today is the Widal test, which is an agglutination reaction. However, widal test is still there are many weaknesses that is low specificity and difficulty in obtaining the standard antigen and require a long time. Other frequent serologic tests include: enzyme immunoassay (EIA) method, enzyme linked immunosorbent assay (ELISA), TUBEX test, Dipstick test, and Dri-dot test. The serologic test has an important value for the diagnosis of typhoid fever. However, there is still wide variation in sensitivity and specificity in the detection of specific antigen S. Typhi because it depends on the type of antigen, the type of specimen examined, the technique used to track the antigen, the type of antibody used in the test (polyclonal or monoclonal) and time of sampling (early or advanced stage in the course of the disease) ${ }^{1}$

Part of S. Typhi that can act as an antigen is (i) Polysaccharide Vi capsule located at the outermost layer, functioning to avoid immune response and phagocytosis, (ii) lipopolysaccharide (LPS) which is virulent and an important antigen for $\mathrm{S}$ typhi, this antigen known as $\mathrm{O}$ antigen is an endotoxin in humans and animals. (iii) a protein flagel known as $\mathrm{H}$ antigen, comprising a protein component responsible for the activity of flagell antigen, but antibody to flagelline can not protect the body against S. Typhi infection. (iv)antigen Outer Membrane 
Protein (OMP) S. Typhi is the cell wall located outside the cytoplasmic membrane and the peptidoglycan layer that limits the cell to its surrounding environment ${ }^{2}$.

OMP's S. Typhi gives result that the protein is very immunogenic and can recognize the whole S. Typhi cell. Furthermore, the protein can be a vaccine candidate. OMP S. Typhi has a very strong immunogenic potential and has been involved as a typhoid fever vaccine candidate. ${ }^{3}$

On previous studies using S. Typhi isolates Makassar with the results that have been reported include: S. typhi has derived from OMP (Outer Membrane Protein) with a molecular weight of about $36 \mathrm{kDa}$. In the study also reported that immunization. ${ }^{4}$

${ }^{I}$ Nakhla, Isabelle et al. Validation of the Dri-Dot Latex agglutination and IgM lateral flow assays for the diagnosis of typhoid fever in an Egyptian population. Diagnostic Microbiology and Infectious Disease, Volume 70, Issue 4, 435 - 441

${ }^{2}$ Sudharmono P, Sylvia YM dan Lucky HM., 2000. Validity Examination of Agglutinin O and H test Salmonella typhi in the diagnosis of Dengue Fever Tifoid, Jakarta, J Trisakti, Volume 19 number 2 pp 82-85

${ }^{3}$ Song, J.H., Helen, C., Y.P. Doe, S.N. Hee, B.M. and Chik, H.P1993. Detection of Salmonella typhi in the blood of patient with typhoid fever by PCR. Clinical Microbiology J.1993, 31(6)1439-1443.

${ }^{4}$ Cut Muthiadin, Rosdiana Natsir, Rosana Agus, Muhammad Nasrum, Ressy Dwiyanti, Muhammad Sabir, Yadi Yasir, and 36 OMP's provide meaningful protectivity in the induction of active immunity against $S$. typhi in mice ${ }^{5}$.

\section{Methods}

\subsection{Culture of S. Thypi}

Blood taken as much as $3 \mathrm{ml}$ aseptically then put into a small transport bottle containing medium Ox Bile Broth $9 \mathrm{ml}$, mixed slowly until homogeneous and incubated at 37oC for 18-24 hours. This culture is then isolated on selective medium (SSA) that has been compacted, diinkuabsi 37oC for 18-24 hours. Then the observation of the colony suspected S. Thypi based on the characteristics of colonies growth. And confirmed with biochemistry test (MR-VP, citrate, glucose)

\subsection{OMP Test with Serum using Latex.}

Wash latex with carbonate-bicarbonate buffer $1 \%$ then add lyophilized OMP with $1 \mathrm{mg}$ ratio in $100 \mathrm{ul}$ Latex. The latex and OMP mixture was then incubated at $37^{\circ} \mathrm{C}$ for 6 hours then blocked with PBS containing $5 \mathrm{mg} /$ $\mathrm{ml}$ of BSA to inhibit the non-specific absorption of other proteins at $37^{\circ} \mathrm{C}$ overnight.Drop5 $\mu$ Latex OMP on agglutination card, then add serum with the same amount. Mix serum and latex using a sterile spatula filled the circle of the agglutination card. While shaking, observe the agglutination changes on the card for 2 minutes. The result is then interpreted. Agglutination occurring under 15 seconds is interpreted $+4,+3$ results if agglutination occurs between 15 to 30 seconds, +2 if agglutination is seen at 30 to 45 seconds, +1 if agglutination is formed between 45 seconds to 1 minute. Meanwhile, if no change in agglutination card above 1 minute is interpreted negatively.

\subsection{LPS Serum Test with Lateral Flow.}

Add $5 \mu \mathrm{l}$ of serum to the hole in the sample then add the running buffer of $130 \mu 1$ or 6 drops from the plastic pipette. Leave it for 10 minutes or until the control line is perfectly formed then interpretation of the result. +4 if the line formed on the test part is brighter than the line formed on the control part, +3 if the test line looks the same as the control line, +2 if the test line is less bright than the test line, +1 if the test line is formed thin and vague, while negative if not formed a line on the test.

\subsection{Ethical Approval and Informed Consent}

Institutional and ethical permission to carry out the study was obtained from the Faculty of Medicine Hasanuddin University Makassar Indonesia. Adult participants and parents/guardians of suspected children provided by informed consent before blood samples were collected. 


\section{Results}

To determine the reactivity ability of OMP protein that has been purified by serum (antibody) of typhoid fever patient, therefore, serology test with dri-dot (latex particles). From the test results between OMP's with serum (dri-dot), then compared with the result of blood culture that still used as standard. Then as a comparative test was tested serum with a rapid diagnostic tool known as lateral flow. (see table 1,2,3)

TABLE I: Blood Culture in Patients Suspected of Typhoid Fever

\begin{tabular}{|clcc|}
\hline & & $\mathbf{N}$ & $\mathbf{\%}$ \\
\hline \multirow{4}{*}{ Culture } & Positive & 5 & 20 \\
& Negative & 20 & 80 \\
& TOTAL & 25 & 100 \\
\hline
\end{tabular}

TABLE II: Dri-Dot Omps Results in Serum Samples of Typhoid Fever Patients

\begin{tabular}{|llrc|}
\hline & & $\mathrm{N}$ & $\%$ \\
\hline \multirow{3}{*}{ DRI-DOT } & Positive & 23 & 92 \\
& Negative & 2 & 8 \\
& TOTAL & 25 & 100 \\
\hline
\end{tabular}

TABLE III: IgM Lateral Flow Results in Serum Samples of Typhoid Fever Patients

\begin{tabular}{|clrc|}
\hline & & N & $\%$ \\
\hline \multirow{3}{*}{ LF IgM } & Positive & 23 & 92 \\
& Negative & 2 & 8 \\
& TOTAL & 25 & 100 \\
\hline
\end{tabular}

TABLE IV: Sera of Typhoid Fever Patients Examined by Dri-Dot Omps and Lateral Flow

\begin{tabular}{|clccc|}
\hline & & \multicolumn{2}{c}{ Dri-dot } & TOTAL \\
& & Positive & Negative & \\
\hline \multirow{3}{*}{ LF IgM } & Positive & 22 & 1 & 23 \\
& Negative & 1 & 1 & 2 \\
& TOTAL & 23 & 2 & 25 \\
\hline
\end{tabular}

From the research results, found 25 samples of tifoid suspect blood were obtained by positive bacteria $\mathrm{S}$. Typhi isolates were $5(20 \%)$, positive tifoid of 22 lateral flow (88\%), and positively typhoid by using purified OMP's protein at latex of $22(88 \%)$

Table V: Comparative evaluation of Dri-dot OMPs and Lateral flow (Blood Culture as a Gold Standard).

\begin{tabular}{|c|c|c|c|c|}
\hline & $\begin{array}{c}\text { No. of positive among } \\
\text { positive culture }(\mathrm{n}=5)\end{array}$ & $\begin{array}{c}\text { No. of positive among } \\
\text { negative culture(n=20) }\end{array}$ & $\begin{array}{c}\text { Sensitivity } \\
(\%)\end{array}$ & $\begin{array}{c}\text { Specifity } \\
(\%)\end{array}$ \\
\hline Dri-dot & 5 & 18 & 21,74 & 100 \\
\hline LF & 5 & 18 & 21,74 & 100 \\
\hline
\end{tabular}

\section{Discussion}

In this study 25 samples from patients suspect tifoid, stored on the transport medium "bactec" which also serves as a media enrichment, after the incubation of the sample is then cultured on MacConkey media, but which can be stated positive or successfully grow on the media only five samples when previously based on patient data it is known that each patient has followed widal test with high enough titer, low sensitivity in blood culture is in accordance with research that has been done Zulfikar A Bhutta and Nasheem M which states the 
sensitivity of blood culture is only around 40-80\% and will be lower in endemic areas due to the high use of antibiotics 1 .

The high levels of antibody titer in a patient can not guarantee the presence of s. Typhi bacteria in patients (septimia) this may be caused by the length of illness or fever of the patient whose blood is drawn, the longer the day of blood taking in typhoid patients the smaller the possibility of bacteria in the patient's blood let alone during the hospital patients routinely consume antibiotics so that although with high antibody titers can not guarantee the presence of s. Typhi bacteria in blood samples of typhoid patients. This is consistent with studies conducted by sylvia and alan which suggest that in association with the pathogenesis of the disease, germs are more easily found in the blood and bone marrow at the onset of the disease, while in later stages in urine and feces 2 .

One of the variables in this study aims to establish diagnostic. diagnostic tests are required with a high specificity, although the sensitivity is not too high. this is in accordance with the results of the study on omp latex with blood culture that is $100 \%$ sensitivity, and low specificity of $21.74 \%$. on the other hand, different results on omp latex with lateral flow are sensitivity of $95.65 \%$ and specificity of $50 \%$. The results presented here showed that all culture positive samples were positive on Lateral Flow and Dri-dot.

\section{Conclusion}

We conclude that there was no difference between Dri-dot OMPs, and lateral flow . Dri-dot OMPs could because for the diagnosis of typhoid fever who have suspected typhoid fever

\section{Acknowledgment}

We would like to say thank you to all the hospital's staff, all participants, and also to my supervisor Prof. DR. MOCH.HATTA PhD for his supporting in my research.

\section{References}

[1] Nakhla, Isabelle et al. Validation of the Dri-Dot Latex agglutination and IgM lateral flow assays for the diagnosis of typhoid fever in an Egyptian population. Diagnostic Microbiology and Infectious Disease, Volume 70 , Issue 4. 2011, pp.435- 441

https://doi.org/10.1016/j.diagmicrobio.2011.03.020

[2] Sudharmono P, Sylvia YM and Lucky HM. Validity Examination of Agglutinin O and H test Salmonella typhi in the diagnosis of Dengue Fever Tifoid, Jakarta, J Trisakti, Volume 19 number 2. 2010. pp 82-85

[3] J.H., Helen, C., Y.P. Doe, S.N. Hee, B.M. and Chik, H.P1993. Detection of Salmonella typhi in the blood of patient with typhoid fever by PCR. Clinical Microbiology J.1993, 31(6)1439-1443.

[4] Muthiadin, C., Natsir, Rosdiana., Agus, Rosana., Nasrum,M., Dwiyanti, Ressy, Sabir, M., Yasir, Y, and Hatta, M. "Identification and Characterization of Antigenic 36 Kda Outer Membrane Protein (OMP) of Salmonella entericaserovar Typhi (S.typhi) from Makassar, South Sulawesi, Indonesia.” American Journal of Biomedical Research, vol. 3, no. 1 (2015): 9-12. doi: 10.12691/ajbr-3-1-3

[5] Muthiadin,C., Hartina, S, St. Aisyah, Mustami, MH. Aziz, Isna Rasdianah. Immunoreactivity of 36 kDa Outer Membrane Protein (OMP) Antigen Salmonella enterica serovar Typhi as Candidate Immunodiagnostic of Typhoid Fever. In: The 5th National and International Conference, 2017, HCU SAMUTPRAKARN THAILAND

\footnotetext{
${ }^{6}$ Zulfiqar Ahmed Bhutta, Naseem Mansurali .Rapid Serologic Diagnosis Of Pediatric Typhoid Fever In An Endemic Area: A Prospective Comparative Evaluation Of Two Dot-Enzyme Immunoassays And The Widal Test. American. Journal of Tropical Medicine Hygiene.. VOL 61(4), 1999, pp. 654-657

${ }^{7}$ Sylvia Retnosari, Alan R. Tumbelaka, Arwin P. Akib, Sri Rezeki Hadinegoro. Clinical and laboratory features of typhoid fever in childhood. The Indonesian Journal of Pediatric and Perinatal Medicines. Vol. 41 (5-6). 2001 pp.56-62
} 
[6] Bhutta, ZA , Mansurali, N .Rapid Serologic Diagnosis Of Pediatric Typhoid Fever In An Endemic Area: A Prospective Comparative Evaluation Of Two Dot-Enzyme Immunoassays And The Widal Test. American. Journal of Tropical Medicine Hygiene.. VOL 61(4), 1999, pp. 654-657

https://doi.org/10.4269/ajtmh.1999.61.654

[7] Retnosari,S., Tumbelaka, AR, Akib,A., Hadinegoro, S.R. Clinical and laboratory features of typhoid fever in childhood. The Indonesian Journal of Pediatric and Perinatal Medicines. Vol. 41 (5-6). 2001 pp.56-62

https://doi.org/10.14238/pi41.3.2001.149-54 